\title{
A Comparative Evaluation of Bidirectional Step-Up DC-DC Converters
}

\author{
Andriazis Dahono and Pekik Argo Dahono \\ School of Electrical Engineering and Informatics, \\ Institute of Technology Bandung, Bandung, INDONESIA
}

\begin{abstract}
This paper presents a comparative evaluation among the modified Cuk, modified buck-boost, and conventional boost bidirectional dc-dc power converters. It is shown that the efficiency of modified dc-dc Cuk power converter is the highest though the component count is the highest. It is also shown that the current ripples can be further reduced by integrating the two inductors of modified dc-dc Cuk power converter in one magnetic core. This paper shows that the modified dc-dc buck-boost power converter has almost no advantage compared to the conventional dc-dc boost power converter. Several experimental results are included to clarify the analysis.
\end{abstract}

Keywords: dc-dc converter, ripple analysis, conduction losses

\section{Introduction}

In order to reduce the $\mathrm{CO} 2$ emission to the atmosphere, it is expected that electric cars will replace the internal combustion engine (ICE) cars in the near future. As a transition to fully electric cars, many manufacturers have produced hybrid and plug-in hybrid cars. Including in this transition is the use of dual dc voltage system in the cars. In conventional ICE cars, the dual dc voltage system is useful to accommodate more electrical loads in the cars that eventually will improve the engine efficiency.

A bidirectional step-up dc-dc power converter is commonly used in modern cars as an interface between one dc voltage and another dc voltage. For example in dual dc voltage conventional ICE cars, a bidirectional step-up dc-dc power converter is used as an interface between $14 \mathrm{~V} \mathrm{dc}$ system and $42 \mathrm{~V}$ dc system. A bidirectional step-up dc-dc power converter is also used in battery charger/discharger. Various dc-dc power converter topologies were proposed and some of them have been put into practices [1]-[21]. In car applications, simplicity, high-efficiency, and high reliability are very important. Moreover, low current ripple and high power density are desirable. For this reason, the most commonly used is the one based on the nonisolated bidirectional boost dc-dc power converter. In order to reduce further the current ripple, the multiphase arrangement is commonly used.

Similar to the developments in photovoltaic power generation systems, a partial rated stepup dc-dc power converter has also been proposed to improve the efficiency of bidirectional boost dc-dc power converter. The partial rated step-up dc-dc power converter is derived from the modification of buck-boost dc-dc power converter [20]-[21]. It is shown here, however, the losses of existing partial rated step-up dc-dc power converter is almost no different to the conventional boost dc-dc power converter. Moreover, the input and output current ripples of this converter are higher than the conventional boost dc-dc power converter as it is derived from buck-boost dc-dc converter.

This paper presents a new bidirectional step-up dc-dc power converter that is derived from Cuk dc-dc power converter. As it is derived from Cuk dc-dc power converter, the input and output currents are continuous with low ripple content. Though the number of passive components is more than conventional boost dc-dc power converter, it is shown theoretically and experimentally that the losses are lower. The expressions of input and output current ripples are derived in this paper. It is also shown that the current ripple can be reduced further by integrating the two inductors into one magnetic core. Several experimental results are included to show the performance of the proposed converter.

Received: April 27th, 2020. Accepted: June 8th, 2020 DOI: $10.15676 /$ ijeei.2020.12.2.13 


\section{Bidirectional Step-Up DC-DC Power Converters}

This section discusses the derivation of the proposed bidirectional dc-dc power converter. The discussion is started by discussing the conventional boost dc-dc power converter and modified buck-boost power converter. The discussion is then followed by the proposed modification of Cuk dc-dc power converter. Here, the discussion neglects the effects of voltage drops across the inductor and switching devices.

The scheme of conventional bidirectional boost dc-dc power converter is shown in Figure 1. Instead of MOSFET, IGBT can also be used as the active switching device. Transistors $Q_{1}$ and $Q_{2}$ receive complementary ON-OFF signals, transistor $Q_{l}$ receives an ON (OFF) signal when transistor $Q_{2}$ receives and OFF $(\mathrm{ON})$ signal. If the load current is positive (negative), the current flows through transistor $Q_{l}\left(D_{l}\right)$ when transistor $Q_{l}\left(Q_{2}\right)$ receives an ON $(\mathrm{OFF})$ signal. When the transistor $Q_{2}\left(Q_{1}\right)$ receives an ON(OFF) signal, the current flows through diode $D_{2}$ $\left(Q_{2}\right)$ when the load current is positive (negative). Under continuous conduction inductor current mode, the average output voltage is

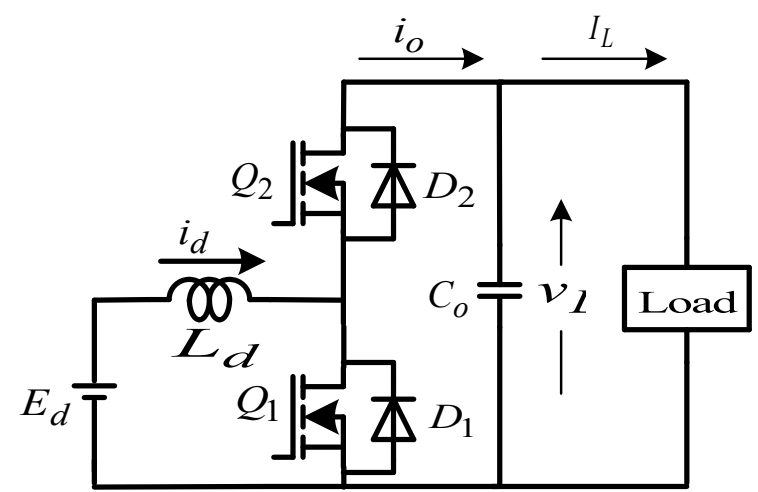

Figure 1. Conventional bidirectional boost dc-dc power converter.

$$
\bar{v}_{L}=\frac{E_{d}}{1-\alpha}
$$

where $\alpha$ is the duty cycle of transistor $Q_{l}$. According to (1), the output voltage is infinite when the duty cycle is closed to unity. In practices, the maximum output voltage is limited due to voltage drops across the inductor and switching devices. Under continuous inductor current mode, the source current is continuous with low ripple content. DC current with low ripple current is important for battery, PV, and fuel cell. The output current, however, is discontinuous with high ripple content. Thus, a large electrolytic output filter capacitor is required. In this conventional dc-dc boost converter, the rated voltages of switching devices and dc filter capacitor are equal to the output voltage.

A partial rated step-up dc-dc power converter has been proposed in [20]-[21] in an attempt to improve the efficiency. This converter can be considered as modification of conventional buck boost dc-dc power converter as shown in Figure 2(a). In this conventional buck-boost dc$\mathrm{dc}$ power converter, the average output voltage under continuous inductor current mode is

$$
\bar{v}_{o}=\frac{\alpha E_{d}}{1-\alpha}
$$

The advantage of this conventional buck-boost dc-dc power converter is the possibility to step-down and step-up the dc voltage. The disadvantages of this converter are discontinuous input and output currents with the associated high ripple content and the output voltage polarity is reversed.

The load of conventional buck-boost dc-dc power converter does not need to be connected to the terminal as shown in Figure 2(a). There is other terminal as shown in Figure 2(a) with average voltage that is equal to (1). If the load is connected to this terminal, the converter became as the one shown in Figure 2(b). In this case, the output voltage is always higher than the input voltage and the output voltage polarity is not reversed. For the same output voltage, 
the required duty cycle of the transistor will become lower than the conventional buck-boost dc-dc converter. Thus, as it is shown later, the losses will be lower compared to conventional buck-boost dc-dc power converter. Compared to conventional boost dc-dc power converter, however, the losses will be the same. The average inductor and switching device currents are the same as conventional dc-dc boost power converter. The difference is only on the rated voltage of the filter capacitor that is lower than the conventional dc-dc boost power converter. The average voltage of the dc filter capacitor is equal to (2). As the input and output currents are discontinuous, this modified buck-boost dc-dc power converter is not recommended for battery charger/discharger.

Figure 3(a) shows the scheme of conventional bidirectional Cuk dc-dc power converter [22]. This converter can also be considered as the dual of conventional bidirectional dc-dc buck-boost power converter. The main advantages of this conventional bidirectional Cuk dc-dc power converter are the continuous input and output currents with low ripple content. The two inductors can be integrated into one magnetic core to save space and to reduce the inductor current ripple. Thus, this converter is suitable for battery charger/discharger, PV power generation system, and fuel cell power conditioner The main disadvantage of this converter is the reversed output voltage polarity. The average dc output voltage of this dc-dc power converter is equal to (2).

Similar to the derivation of modified buck-boost dc-dc power converter, there is other terminal that can be used as a load terminal as shown in Figure 3(a). If this terminal is used then the modified bidirectional Cuk dc-dc power converter is obtained as the one shown in Figure 3(b). The average output voltage of this new converter is the same as (1). The average dc output filter capacitor is the same as the modified bidirectional buck-boost dc-dc power converter that is lower than the conventional boost dc-dc power converter. Moreover as the output current is continuous, the rated current ripple of the dc output filter capacitor will be much lower than the conventional boost dc-dc power converter. The main disadvantages of

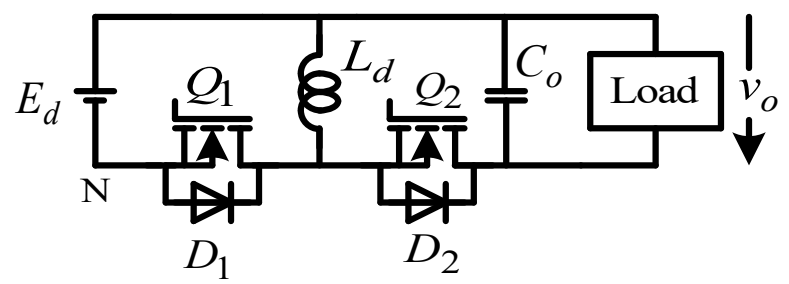

(a)

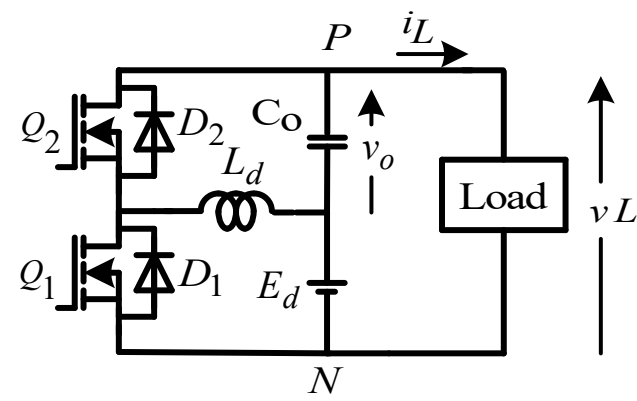

(b)

Figure 2. (a) Conventional and (b) modified bidirectional buck-boost dc-dc converters. 


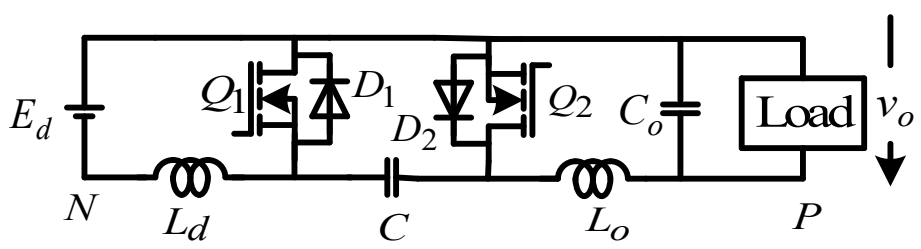

(a)

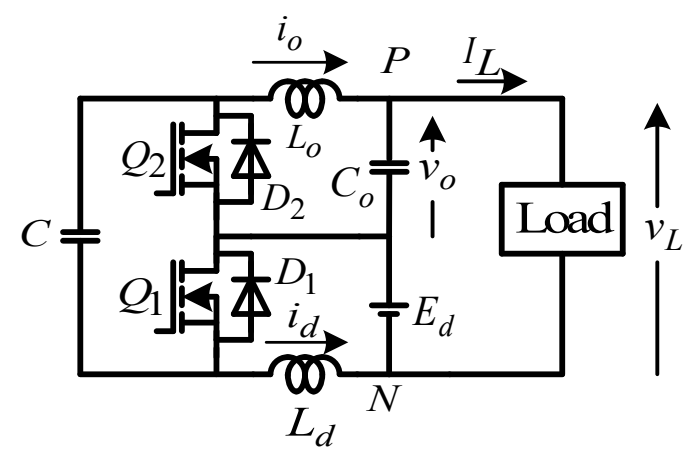

(b)

Figure 3. (a) Conventional and (b) modified bidirectional Cuk dc-dc converters.

using modified Cuk dc-dc power converter are the need of additional capacitor $C$ and one more inductor. Though additional inductor is required, it is shown here that the losses are lower than the losses of conventional bidirectional boost and modified buck-boost dc-dc power converters.

\section{Output Voltage Comparison}

The three step-up dc-dc power converters have the same output voltage as shown by (1). This expression has been derived by neglecting the voltage drops across the inductors and switching devices. In practices, these voltage drops cannot be neglected. Due to these voltage drops, the maximum output voltages are limited. Moreover, these voltage drops create conduction losses in these dc-dc power converters.

By using a simple state-space averaging technique, it can be shown that the average output voltage of conventional boost dc-dc power converter is

$$
\bar{v}_{2}=\frac{E_{\alpha}-v_{Q} \alpha-v_{D}(1-\alpha)}{1-\alpha}-\frac{R_{\alpha}+R_{Q}^{\alpha+R_{D}}(1-\alpha)}{(1-\alpha)^{2}} I_{2}
$$

when the load current is positive, and

$$
\bar{v}_{2}=\frac{E_{\alpha}+v_{Q}(1-\alpha)+v_{Q} \alpha}{1-\alpha}+\frac{R_{\alpha}+R_{Q}(1-\alpha)+R_{Q} \alpha}{(1-\alpha)^{2}} I_{L}
$$

when the load current is negative. In deriving (3) and (4), it is assumed that the voltage drops during conduction state are

$$
v_{Q}=V_{Q}+R_{Q} i_{Q}
$$

for the transistor, and

$$
v_{D}=V_{D}+R_{D} i_{D}
$$

for the diode. In (3) and (4), $R_{d}$ is the resistance of boost inductor $L_{d}$. The filter capacitor is assumed as an ideal capacitor.

By using the same method, it can be shown that the output voltage of modified bidirectional buck-boost dc-dc power converter in Figure 2(b) is the same as given by (3) and (4). Thus, the voltage characteristics of modified bidirectional buck-boost and conventional bidirectional boost dc-dc power converters are the same. Once again by using the same method, the output voltage of modified bidirectional Cuk dc-dc power converter is 


$$
\bar{v}_{2}=\frac{E_{\alpha}-v_{Q} \alpha-v_{Q}(1-\alpha)}{1-\alpha}-\frac{R_{\alpha}\left(1-2 \alpha+2 \alpha^{2}\right)+R_{Q} \alpha+R_{Q}(1-\alpha)}{(1-\alpha)^{2}} I_{L}
$$

when the load current is positive, and

$$
\bar{v}_{L}=\frac{E_{\alpha}+v_{Q}(1-\alpha)+v_{Q} \alpha}{1-\alpha}+\frac{R_{\alpha}\left(1-2 \alpha+2 \alpha^{2}\right)+R_{Q}(1-\alpha)+R_{Q} \alpha}{(1-\alpha)^{2}} I_{L}
$$

when the load current is negative. In deriving (7) and (8), it is assumed that the inductors $L_{d}$ and $L_{o}$ have the same resistances that are equal to $R_{d}$.

Eqns. (3)-(4) and (7)-(8) show that the voltage drop across the inductors in modified Cuk dc$\mathrm{dc}$ power converter is lower than the ones in modified buck-boost and conventional boost dc-dc converters. If both sides of (3) are multiplied by $\mathrm{I}_{\mathrm{L}}$, the result is

$$
\bar{v}_{L} I_{L}=\frac{E_{\alpha}-v_{Q} \alpha-v_{Q}(1-\alpha)}{1-\alpha} I_{L}-\frac{R_{\alpha}+R_{Q^{\alpha}}+R_{Q}(1-\alpha)}{(1-\alpha)^{2}} I_{L}^{2}
$$

The source current of the converter is

$$
\bar{I}_{s}=I_{L}(1-\alpha)
$$

Based on (9) and (10) then the losses of conventional bidirectional boost and modified bidirectional buck-boost dc-dc power converters under positive load current are

$$
\begin{aligned}
& P_{\text {[Qs }}=E_{d} \bar{I}_{s}-\bar{v}_{l} I_{2} \\
& =\frac{\left[v_{Q} \alpha+v_{0}(1-\alpha)\right]}{1-\alpha} I_{2}+\frac{R_{\alpha}+R_{Q} \alpha+R_{O}(1-\alpha)}{(1-\alpha)^{2}} I_{L}^{2}
\end{aligned}
$$

By using the same method, the losses of modified Cuk dc-dc power converter is

$$
P_{\text {[oss }}=\frac{\left[v_{Q} \alpha+v_{Q}(1-\alpha)\right]}{1-\alpha} I_{L}+\frac{R_{\alpha}\left(1-2 \alpha+2 \alpha^{2}\right)+R_{Q} \alpha+R_{Q}(1-\alpha)}{(1-\alpha)^{2}} I_{L}^{2}
$$

Comparison between (11) and (12) shows that the conduction losses of modified bidirectional Cuk dc-dc power converter are lower than both modified bidirectional buck-boost and conventional bidirectional boost dc-dc power converters.

Figure 4 shows the plot of eqns. (11) and (12) when the switching devices are assumed as ideal devices with no voltage drops. This figure shows clearly that the losses in modified Cuk power converter are the lowest compared to the other two power converters. As the switching losses of these three converters are the same, the efficiency of modified bidirectional Cuk dcdc power converter will be the highest.

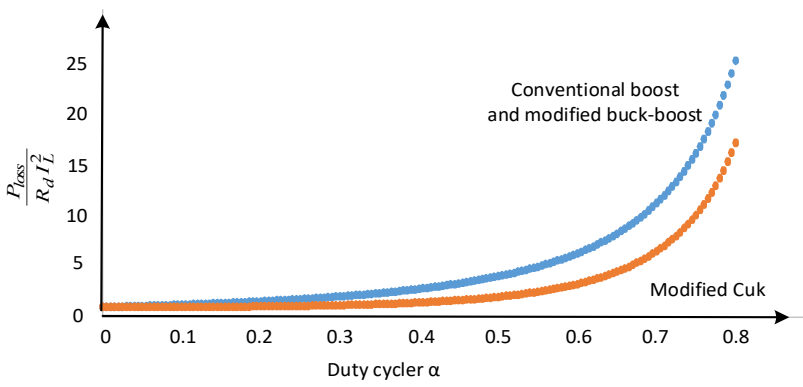

Figure. 4. Loss comparison.

\section{Ripple Comparison}

Ripple analysis is important to determine the required inductors and capacitors. In this section, the inductor current ripples, capacitor current ripples, and source current ripple of the three dc-dc power converters are compared. By using a simple time domain analysis, it can be shown that the inductor current ripples of modified bidirectional Cuk dc-dc power converter are

$$
\begin{aligned}
& l_{d}=\frac{i_{\mathrm{a}}-\beta \alpha}{2 \sqrt{3} \Delta} \frac{\alpha E_{\alpha d}}{f_{s}} \\
& l_{0}=\frac{i_{\alpha}-3 \alpha}{2 \sqrt{3} \Delta} \frac{\alpha E_{\alpha d}}{f s}
\end{aligned}
$$


where $M$ is the mutual inductance between the two inductors in modified bidirectional dc-dc Cuk power converter, and

$$
\Delta=L_{d} L_{0}-M^{2}
$$

Eqns. (13) and (14) show that the inductor current ripples can be reduced by coupling the two inductors in one magnetic core. The inductor current ripple (13) is the same as the source current ripple. The inductor current ripple (14) is the same as the current ripple that must be absorbed by the output filter capacitor $C_{o}$.

The rms value of ripple current through the transfer capacitor $C$ can also be obtained as

$$
I_{c}=I_{L}\left(\frac{\alpha}{1-\alpha}\right)^{1 / 2}
$$

As this capacitor current ripple is high, it is recommended to use nonelectrolytic type for the transfer capacitor $C$. This current ripple cannot be reduced by increasing the switching frequency.

The inductor current ripples of modified buck-boost and conventional boost dc-dc power converters are the same as given below

$$
l_{d}=\frac{1}{2 \sqrt{3} i_{d d}} \frac{\alpha E_{d}}{f_{s}}
$$

In the case of conventional bidirectional boost dc-dc power converter, the inductor current ripple (17) is the same as the source current ripple. In the case of modified bidirectional buckboost dc-dc power converter, the rms value of source current ripple is

$$
l_{s}=I_{L}\left(\frac{\alpha}{1-\alpha}\right)^{1 / 2}
$$

The current ripples that must be absorbed by the output filter capacitors of modified buckboost and conventional boost dc-dc power converters are the same, that is

$$
I_{0}=I_{2}\left(\frac{\alpha}{1-\alpha}\right)^{1 / 2}
$$

As the size of capacitor is mostly determined by the ripple current rating, the size of output filter capacitor of modified bidirectional Cuk dc-dc power converter will be the lowest.

For summary, Table 1 shows comparison among the modified bidirectional Cuk, modified buck-boost, and conventional boost power converters. In order to simplify the comparison, it is assumed that the two inductors of modified bidirectional Cuk dc-dc power converter are equal with inductance of $L_{d}$. Moreover, it is also assumed that the two inductors are uncoupled. Though the component count is the highest, the modified bidirectional Cuk dc-dc power converter has the highest efficiency. The modified bidirectional; buck-boost converter dc-dc has almost no advantage compared to conventional bidirectional boost dc-dc power converter. As the input and output currents of modified Cuk dc-dc power converter are continuous, this converter is suitable for PV and fuel cell power generation systems. This converter is also suitable for battery charger/discharger as it is found in automotive systems.

\section{Experimental Results}

A small experimental system as the one shown in Figure 3(b) was constructed. Two power MOSFETs were used as switching devices in this experiment. Uncoupled two equal inductors of $2.2 \mathrm{mH}$ were used as $L_{d}$ and $L_{o}$. The switching frequency of power converter can be varied from $5 \mathrm{kHz}$ up to $10 \mathrm{kHz}$. The capacitance $C$ is $1000 \mathrm{uF}$ and the capacitance $C_{o}$ is $1000 \mathrm{uF}$. The $\mathrm{dc}$ source is obtained from a dc power supply that is maintained constant at $36 \mathrm{Vdc}$. A constant load of $107 \mathrm{Ohm}$ was used as the load in this experiment.

Figure 5 shows the output voltage as the function of duty cycle of the modified Cuk converter. Ideal curve is the calculated results when the voltage drops across the switching devices and inductors are neglected. The nonideal curve is calculated results when the voltage drops are taken into account as given by (6). Measurements were conducted under two switching frequencies. It can be seen that the derived expression is accurate in predicting the output voltage.

Figure 6 shows the experimental and calculated results of current ripple through inductor $L_{d}$ of the modified Cuk converter. The current ripple is measured by using a digital ampere meter 
that able to measure the ripple current component separately from the dc component. Very good agreement between calculated and experimental results can be appreciated from this figure. Similar results are obtained for current ripple through inductor $L_{o}$. Similar to other dc-dc converters, the output filter capacitor current ripple can be reduced further by multiphasing technique.

Figure 7 shows the efficiency of the modified Cuk dc-dc converter when the duty cycle is changed. The load resistance during this experiment was constant. As it is predicted, the efficiency is higher when the duty cycle is small. When the duty cycle is small, the efficiency can be up to $99 \%$. The efficiency can be increased by reducing the resistances of the inductors. Moreover, the losses across the switching devices can also be reduced by using modern power devices [10].

Figure 8 shows the current through the inductor $L_{d}$ when the power flow is reversed. In this experiment, another dc voltage source was connected in parallel to the load. The duty cycle of the power converter is then adjusted to make the power flow is reversed. This figure shows the bidirectional power flow capability of the proposed power converter.

Table 1. Comparison of bidirectional step-up dc-dc power converters.

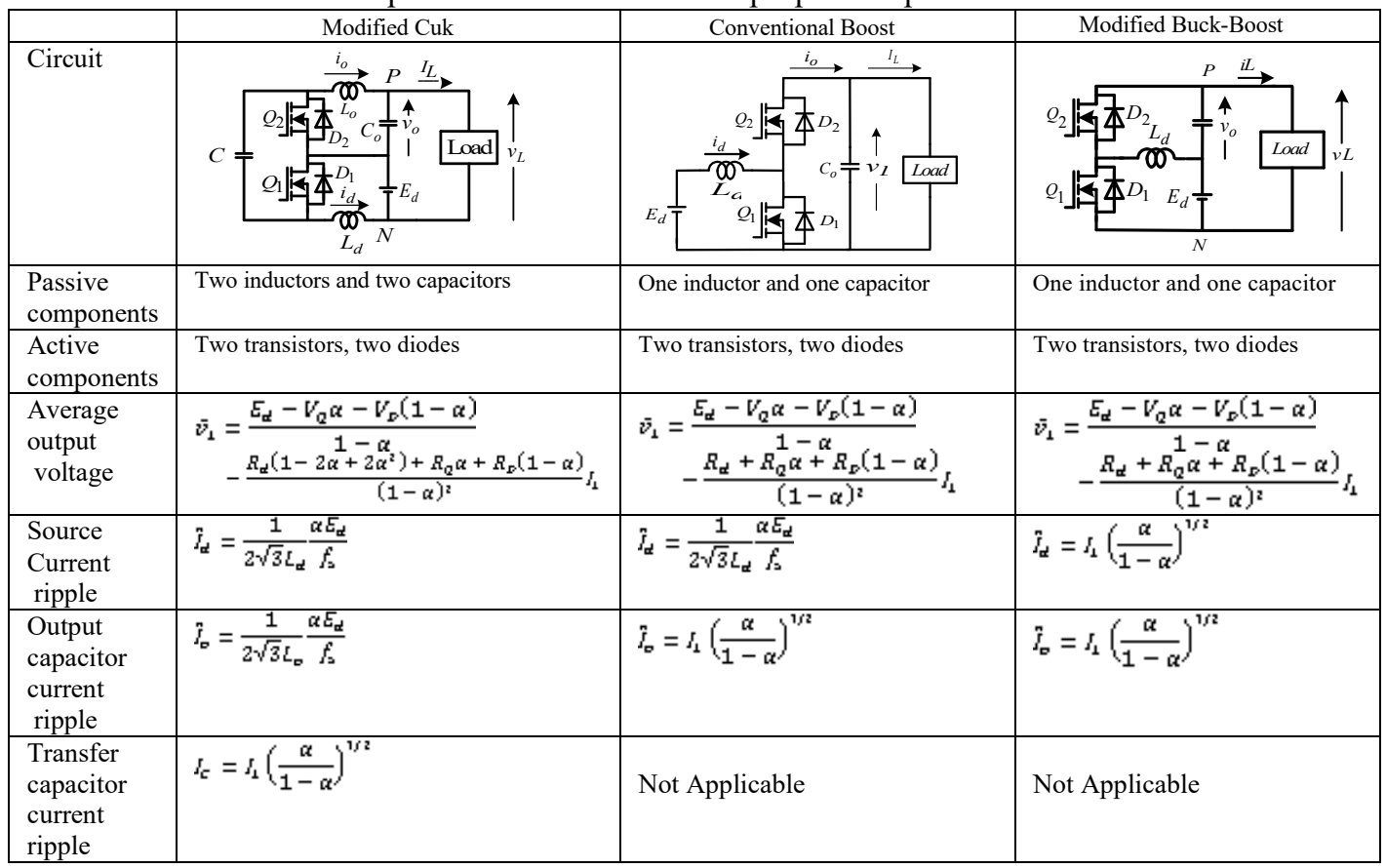

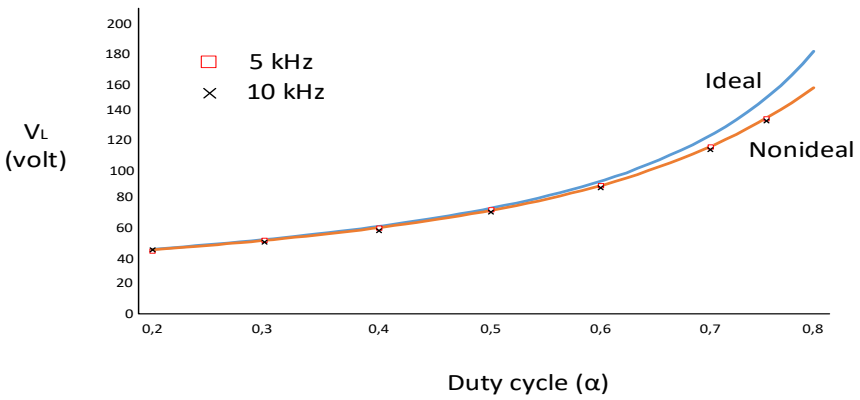

Figure 5. Measured and calculated output voltage as a function of duty cycle for modified Cuk converter. 


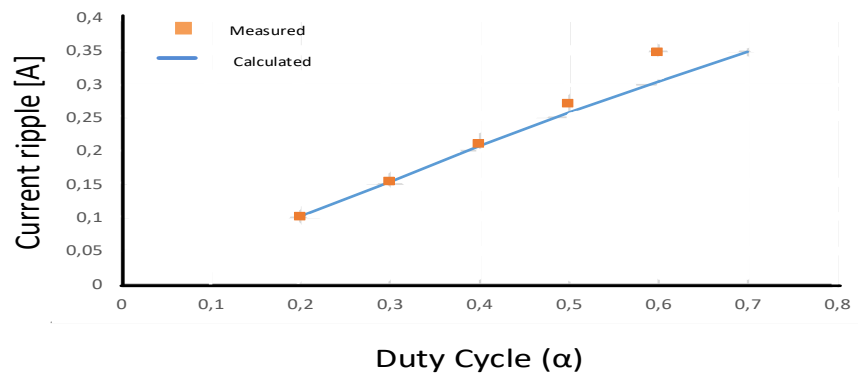

Figure 6. Measured and calculated results of inductor current ripple for modified Cuk converter.

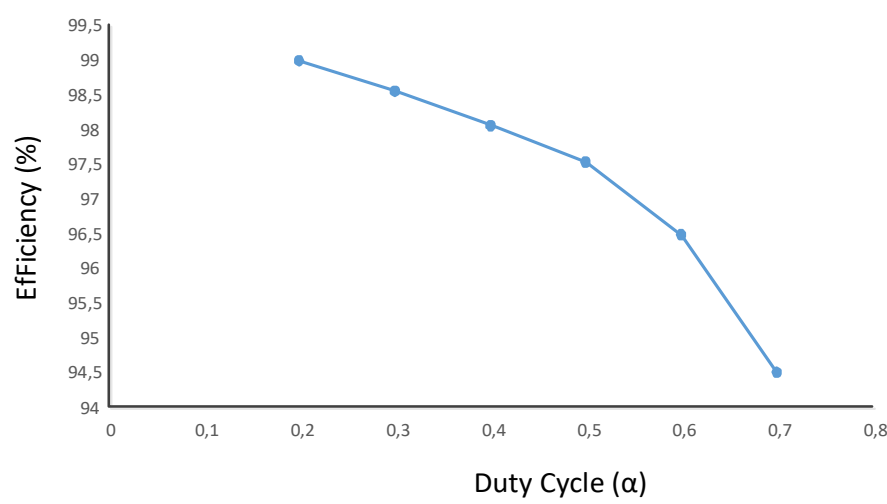

Figure 7. Measured efficiency of modified Cuk converter.

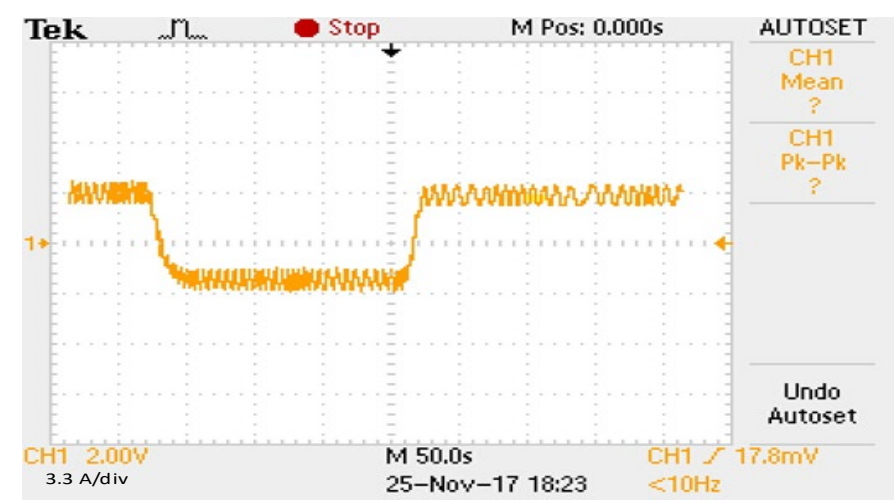

Figure 8. Inductor $L_{d}$ current of modified Cuk converter when the power flow is reversed.

\section{Conclusion}

Performances of three bidirectional step-up dc-dc power converters have been compared in this paper. Though the component count of modified bidirectional Cuk dc-dc power converter is the highest, the efficiency is the highest compared to other two bidirectional dc-dc power converters. The modified bidirectional step-up Cuk dc-dc power converter has continuous input and output currents with lower ripple content. The derived expressions are useful in designing the proposed bidirectional dc-dc power converter. Experimental results are included to verify the analysis results. 


\section{Acknowledgments}

The authors wish to thank Korea Midland Power Company, PT. LEN (Persero), and LPDP for financial support.

\section{References}

[1] F. Peng, F. Zhang, and Z. Qian, 'A Magnetic-Less DC-DC Converter for Dual-Voltage Automotive Systems' IEEE Trans. Ind. Appl., Vol. 39, No. 2, March/April 2003, pp. 511518.

[2] A. Consoli, et.al., 'A multiphase $\mathrm{dc} / \mathrm{dc}$ converter for automotive dual-voltage power systems', IEEE Industry Appl. Mag., Nov./Dec. 2004, pp. 35-42.

[3] M. Gerber, et.al., 'High Density Packaging of the Passive Components in an Automotive DC/DC Converter', IEEE Trans. Power Electron., Vol. 20, No. 2, March 2005, pp. 268275.

[4] S. Lee, A. Pfaelzer, and J. Wyk, 'Comparison of Different Designs of a 42-V/14-V DC/DC Converter Regarding Losses and Thermal Aspects', IEEE Trans. Ind. Appl., Vol. 43, No. 2, March/April 2007, pp. 520-530.

[5] D. Ha, et.al., 'Interleaved Bidirectional DC-DC Converter for Automotive Electric Systems', IEEE Industry Appl. Soc. Annual Meet., 2008.

[6] S. Waffler, J. Biela and, J. Kolar, 'Output Ripple Reduction of an Automotive MultiPhase Bi-Directional DC-DC Converter', Conf. Rec. IEEE Energy Conversion Congress and Expo, 2009, pp. 2184-2190.

[7] Y. Du, et.al., 'Review of Non-isolated Bi-directional DC-DC Converters for Plug-in Hybrid Electric Vehicle Charge Station Application at Municipal Parking Decks', IEEE Applied Power Electron. Conf. Rec., 2010, pp. 1145-1151.

[8] L. Yang and T. Liang, 'Analysis and Implementation of a Novel Bidirectional DC-DC Converter', IEEE Trans. Ind. Electron., Vol. 59, No. 1, January 2012, pp. 422-434.

[9] C. Lin, L. Yang, and G. Wu, 'Study of a non-isolated bidirectional DC-DC converter', IET Power Electron., 2013, Vol. 6, pp. 30-37.

[10] D. Han, J. Noppakunkajorn, and B. Sarlioglu, 'Comprehensive Efficiency, Weight, and Volume Comparison of SiC- and Si-Based Bidirectional DC-DC Converters for Hybrid Electric Vehicles', IEEE Trans. Vehicular Tech., Vol. 63, No. 7, September 2014, pp. 3001-3010.

[11] X. Jia, et.al., 'A High Power Density and Efficiency Bi-directional DC/DC Converter for Electric Vehicles', Conf. Rec. IEEE Energy Conversion Congress and Expo Asia, 2015, pp. 874-880.

[12] Y. Yang, et.al., 'A New Coupled-Inductor Structure for Interleaving Bidirectional DCDC Converters', IEEE Emer. Select. Topics Power Electron., Vol. 3, No. 3, Sept. 2015, pp. 841-849.

[13] S. Dusmez, A. Hasanzadeh, and A.Khaligh, 'Comparative Analysis of Bidirectional Three-Level DC-DC Converter for Automotive Applications', IEEE Trans. Ind. Electron., Vol. 62, No. 5, May 2015, pp. 3305-3315.

[14] M. Khan, et.al., 'Performance Analysis of Bidirectional DC-DC Converters for Electric Vehicles', IEEE Trans. Ind. Appl., Vol. 51, No. 4, July/August 2015, pp. 3442-3452.

[15] H. Le, K. Orikawa, and J. Itoh, 'Clarification of Relationship between Current Ripple and Power Density in Bidirectional DC-DC Converter', IEEE Applied Power Electron. Conf. Rec., 2016, pp. 1191-1918.

[16] A. Khan, et.al., 'A Family of High Efficiency Bidirectional DC-DC Converters Using Switching Cell Structure', Conf. Rec. IEEE Energy Conversion Congress and Expo Asia, 2016.

[17] Y. Wang, et.al., 'Interleaved High Conversion-Ratio Bidirectional DC-DC Converter for Distributed Energy-Storage Systems-Circuit Generation, Analysis, and Design', IEEETrans. Power Electron., Vol. 31, No. 8, August 2016, pp. 5547-5561. 
[18] A. Stippich, et.al., 'Key Components of Modular Propulsion Systems for Next Generation Electric Vehicles', CPSS Trans Power Electron. Appl., Vol. 2, No. 4, Dec. 2017, pp. 249258.

[19] S. Gorji, et.al., 'Topologies and Control Schemes of Bidirectional DC-DC Power Converters: An Overview', IEEE Access, Vol. 7, 2019, pp. 117997-118019.

[20] M. Kasper, D. Bortis, and J. Kolar: 'Classification and Comparative Evaluation of PV Panel-Integrated DC-DC Converter Concepts', IEEE Trans. Power Electron., Vol. 29, No. 4, May 2014, pp. 2511-2526.

[21] I. Osman, D. Xiao, and M. Rahman, 'Analysis of a Cascaded High-Boost Non-Isolated DC-DC converter With Bidirectional Power Flow', IEEE Southern Power Electron. Conf. Rec., 2016, pp. 1-6.

[22] S. Cuk and R. Middlebrook, 'A New Optimum Topology Switching dc-to-dc Converter', IEEE Power Electron. Spec. Conf. Rec., 1977, pp. 160-169.

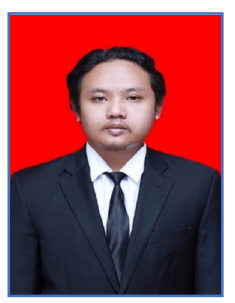

ANDRIAZIS DAHONO was born in Bandung, Indonesia, in 1994. He received the Bachelor Engineering degree in Electrical Engineering from the Institut Teknologi Sepuluh Nopember, Surabaya, Indonesia, in 2018. His fields of interest are power electronics and power system. He is a recipient of the Korea Midland Power Company Scholarships. He has experience of conducting several power quality studies in several industries. At present, he is a graduate student at the Institute of Technology Bandung, Indonesia. He is a student member of IEEE.

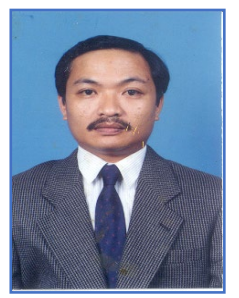

PEKIK ARGO DAHONO was born in Yogyakarta, Indonesia, in 1962. He received the Engineer degree from the Institute of Technology Bandung, Indonesia, the Master and Doctor of Engineering degrees from Tokyo Institute of Technology, Japan, in 1985, 1992 and 1995, respectively, all in electrical engineering.

His fields of interest are power electronics, power quality, and electrical machinery. He is a recipient of the PII and ASEAN Outstanding Engineering Achievement awards in 2006. He has published more than 100 papers in international conferences and journals. He has received several best paper awards. He is registered as Fellow Professional Engineer, in Indonesia, and ASEAN Chartered Professional Engineer. At present, he is a professor in the School of Electrical Engineering and Informatics, Institute of Technology Bandung, Indonesia. He is a senior member of IEEE. 